\title{
Memory and Forgetting on the National Periphery: Marseilles and the Regicide of 1934
}

\author{
Matthew Graves, University of Provence (Aix-Marseille Université)
}

'Study reveals that, even at the social level, memory is a structure of forgetfulness' (Rousso 1991: 4).

\section{Introduction}

A pedestrian strolling down the Canebière towards the Vieux Port of Marseilles might be forgiven for overlooking one of the more discreet landmarks in the city's memorial landscape: the plaque opposite the Palais de la Bourse commemorating the double assassination of Alexander I, King of Yugoslavia, and Louis Barthou, the French Minister of Foreign Affairs, who were shot dead by a Croation nationalist at the foot of the Canebière, a few hundred yards from the Quai des Belges, on 9 October 1934 (Borne \& Dubief 1989: 120; Berstein 1988: 157). Disguised as public lighting and designed to merge into the urban landscape, the plaque does little to draw attention to itself. The pedestrian would have to glance skywards to notice the inscription: 'Here the valiant King Alexander of Yugoslavia, friend of Marseille and of France, and President Louis Barthou, laid down their lives for peace and liberty ... 9 October $1934^{\prime 1}$ [see figure one].

In hindsight, political commentators and historians have seen the events of 1934 as an early portent of war, 'a premonition of a broader tragedy which was to be unleashed

\footnotetext{
1 'Ici sont tombés pour la paix et la liberté le roi preux Alexandre de Yougoslavie, ami de Marseille et de la France et le Président Louis Barthou ... 9 octobre 1934.' All translations are the author's own unless otherwise indicated.
} 
upon the world five or six years later' (Busquet 1998: 386), ${ }^{2}$ highlighting the contrast between the profound political repercussions of the tragedy and its muted memorial treatment. The relegation of the regicide to the minor genre of public memorialism- the commemorative plaque (Dutour 2006) — and its neglect through non-observance, are apparent anomalies that raise issues of universal relevance beyond the particulars of the present case study: about the preservation of traumatic memories, especially those tainted by political violence with an adverse impact on group, institutional or community identities; about the conflicting claims of national, regional and local commemorative agencies over sites of memory located on the periphery of the national arena; and, lastly, about the appropriation of monuments and memorials' symbolic power by dissident voices at times of social crisis or hiatus and their use in the construction of counter-narratives to 'official memory.'

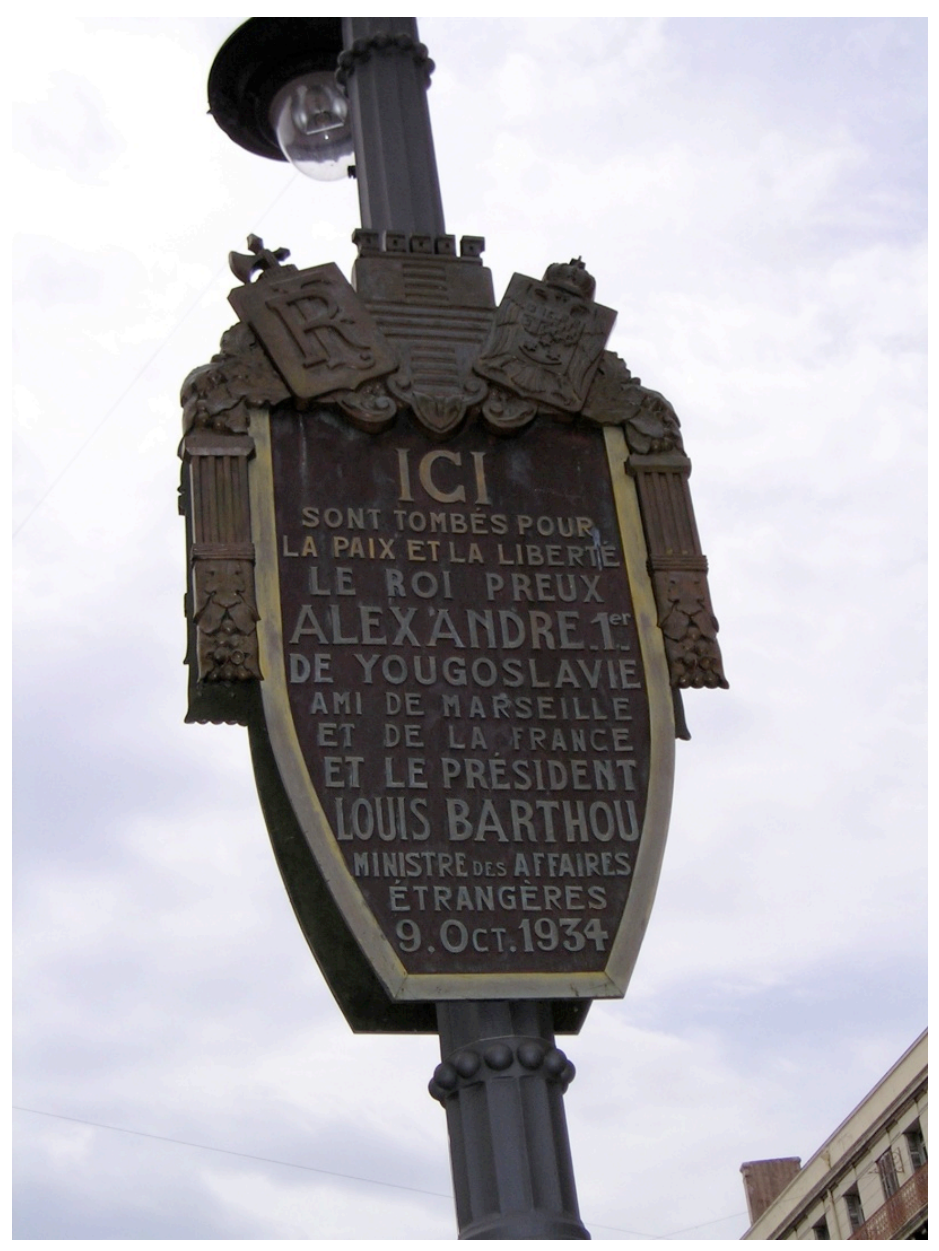

Figure 1: Alexander I memorial plaque (C) Matthew Graves

\footnotetext{
2 'Il fut comme une prémonition d'une tragédie plus vaste qui, cinq ou six ans plus tard, devait se déployer sur le monde.'
} 
Alexander I was on a state visit to France, at the invitation of President of the Council of Ministers Gaston Doumergue and President of the Republic Albert Lebrun. Louis Barthou, who had previously travelled to Belgrade in June 1934 to negotiate a multilateral security pact with Yugoslavia, was the King's official host, greeting him as he disembarked from the cruiser Dubrovnik on the Quai des Belges minutes before the drama. The shuttle diplomacy was part of Barthou's strategy of containment of Hitlerian Germany aimed at reconciling differences between Yugoslavia and Italy as a prerequisite to drawing Mussolini's Italy into a security pact with the countries of the Little Entente, brokered and guaranteed by France. Marseilles was to have been the showcase first leg of the royal visit: a summit meeting had been planned with Président du Conseil Gaston Doumergue in Paris the next day, on 10 October. But that was precluded by the assassination of Alexander I and Barthou the day before.

The choice of Marseilles as a point of arrival is significant in terms of political symbolism. Alexander Karagjorgjevic (1888-1934), 'the friend of France,' was a former St Cyrien who had distinguished himself as the supreme commander of the Serbian Army in the Balkan campaign against Austro-German forces during World War One, serving alongside Marshal Franchet d'Esperey, commander of the Allied armies in Eastern Europe. The Armée d'Orient had embarked from Marseilles and was commemorated by the Monument aux morts de l'Armée d'Orient et des terres lointaines, designed by the Marseilles architect and WWI veteran Gaston Castel, and inaugurated by President Gaston Doumergue on 24 April 1927 (Drocourt 1988: 78-80). That monument was to have provided the focal point of the King's visit to the city: the planned itinerary included a wreath-laying ceremony intended to underline FrancoYugoslavian amity at the site on the Corniche in the presence of veterans of the campaign. Morevover, a ceremonial sequel had been planned for the Paris leg of the state visit where Alexander was to have previewed a statue to his father, Peter I of Yugoslavia. If memorials provided the backdrop to Alexander's visit, as we shall see, they were soon to come to the fore in the political struggle between Paris and Marseilles over the 'rights to remembrance.'

In France, the political fall-out from the assassination was substantial and wide-ranging. It led directly to the resignations of Albert Sarraut, the French Minister of the Interior and of Jean Berthoin, Director of the National Police (la Sûreté nationale), as well as to 
the suspension of the Prefect for the Department of the Bouches-du-Rhône. Having lost his two leading ministers, Doumergue, who had emerged from semi-retirement to lead the government after the anti-Republican riots of 6 February 1934, resigned in his turn on 8 November 1934, but not before appointing Pierre Laval to replace Barthou as Foreign Minister. The diplomatic consequences of the Germanophile Laval's appointment were to be the progressive abandonment of Barthou's policy aimed at the encirclement and containment of Germany and the adoption of a more conciliatory attitude to the fascist regimes (Warner 1968: 60-61).

The international impact of Alexander and Barthou's deaths was equally far-reaching. The event dominated news headlines around the world, making media history as the first political assassination to be captured on newreel (McNamee 1934). One contemporary commentator, R.W. Seton-Watson, compared the political significance of the assassination to that of Archeduke Franz Ferdinand at Sarajevo in 1914 (1935: 34). Anthony Eden subsequently declared that 9 October 1934 was the day when the first shots were fired in the Second World War (1962: 8), an opinion shared by Harold Macmillan (1966: 161). In a grim assessment of the diplomatic fallout from the assassination, the Foreign Secretary Sir John Simon informed the British cabinet that the government of Yugoslavia had been effectively decapitated: since Alexander's successor Peter II was still a minor, Yugoslavia would be governed by a regency, with unpredictable consequences (Cabinet 1934: 28). On reaching New York, the news provoked a crash on Wall Street. In short, the event appears of greater historical moment than the modesty of its commemorative materialisation and its place in the history manuals would allow. ${ }^{3}$ For instance, in the seventeenth edition of Bouillon, Sorlin and Rudel's 700 page Le Monde Contemporain (1968), a standard history textbook for French secondary schools, the assassination is relegated to a laconic footnote: '(I) Louis Barthou was assassinated in Marseilles in October 1934 along with King Alexander of Yugoslavia whom he had gone there to greet' (215). ${ }^{4}$ And while the

\footnotetext{
${ }^{3}$ For the view that the killing of Alexander and Barthou set in motion the chain of events leading to the Second World War see Deac (1998: 18).

4 '(I) Louis Barthou fut assassiné à Marseille en octobre 1934, en même temps que le roi Alexandre de Yougoslavie qu'il était allé accueillir.' Published by Bordas in 1968, this edition of the school textbook is divided into three sections: World History 1914-1945; the Great Civilisations of the World; and Primary Source Documents. The regicide is discussed in the first of the sections, written by Jacques Bouillon (a lecturer at the Institut d'Etudes Politiques in Paris and Professeur agrégé d'Histoire at the Lycée Henri IV) in a chapter devoted to international relations from 1930 to 1939, under the sub-heading 'Les échecs de la Sécurité Collective (1931-36).'
} 
formula is modulated in subsequent editions, ${ }^{5}$ the reason for Barthou's disappearance from the international scene is consistently sidelined, so that the discontinuity in French foreign policy is barely accounted for, whereas an earlier assassination, that of Chancellor Dollfuss by Austrian Nazis in July 1934, is foregrounded as the more significant international event. ${ }^{6}$

In Philippe Joutard's Histoire de Marseille en Treize Evénements, the assassination is excluded from the list of landmark events that make up the city's 2,600-year history, from its foundation to the present day. In the twentieth century, that place was taken by the Colonial Exhibiton of 1906, and the infamous Nazi-Vichy épuration or 'cleansing' of 22-23 January 1943 (Joutard 1998: 194) which saw the Panier-the old quarter overlooking the Vieux Port - dynamited, and 1,400 of its 20,000 displaced inhabitants deported to concentration camps. ${ }^{7}$ The assassination is mentioned only in passing as a traumatic memory, one that contributed to the 'mauvaise réputation' of Marseilles in modern times (197). Yet even that memory has faded from the collective consciousness of the city. It is absent from the realms of communicative memory-seventy-five years on the last living eye-witnesses were children (or at most adolescents) in 1934 and their testimony has gone largely unrecorded - as well as from the arena of public ceremonial: there is no trace of commemorative observance, either official or unofficial, continuing at the memorial sites beyond the early 1940s.

\footnotetext{
${ }^{5}$ Compare the treatment of the regicide and Barthou's ministry in the 1968 edition with the 1980 edition. On first reading, the episode is repeated almost verbatim, but there is a subtle semantic shift in the later edition: 'Mais le successeur de Barthou, assassiné à Marseille en même temps que le roi Alexandre $1^{\text {er }}$ de Yougoslavie, Pierre Laval, tout en affirmant poursuivre la même politique, en infléchit l'orientation' (302-4). The suppression of the adverb, the integration of the footnote into the main text, the awkward syntax, all suggest a modulation of Laval's responsibility in the redirection of French foreign policy after October 1934. The memory of Barthou becomes indistinguishable from that of his successor Pierre Laval; France is robbed of a diplomatic alternative by a stray bullet, bereft of reason (the proof of a Hungarian or Italian hand in events, for instance), drawing significance from its transitivity with the past anticipated and the road to war.

${ }^{6}$ Bouillon (Bouillon et al. 1980) places Barthou's ill-fated tenure as Foreign Minister in the context of the collapse of the collective system of international security in the early 1930s, precipitated by Germany's withdrawal from the League of Nations on 14 October 1933. Barthou's attempt to set up a comprehensive substitute system of mutual aid across Europe and his success in tightening France's ties with the countries of the Little Entente - Czechoslovakia, Romania, and Yugoslavia - in the course of that endeavour are commended and sharply contrasted with the policies of his successor, Pierre Laval. In textbook histories the figure of Laval looms large over the events of 9 October 1934.

${ }^{7}$ The event is commemorated by a wall plaque on the Place de l'Opéra: 'Les 22 et 23 janvier 1943, 250 familles marseillaises ont été livrées à la gestapo par la Police de Vichy pour l'unique raison d'être nées juives. Déportés et exterminés dans les chambres à Gaz de Sobibor et d'Auschwitz. Hommes, femmes, enfants, aucun ne revint! Toi qui passe, souviens-toi! Ta mémoire est leur seule sépulture. 1943-1993 Amicale d'Auschwitz.' For a detailed discussion of the episode, see Crane (2004: 299-304) who concludes that 'the operation was a dramatic warning intended to quell growing opposition to the German occupation of Marseille' (302).
} 


\section{Peripheral sites and adverse memories}

Would it be fair, then, to describe 9 October 1934 as a failed site of memory, able to be assimilated into the cultural geographer's conception of 'failed place'? If we accept Tim Cresswell's definition that place is space invested with meaning (2004: 10), the significance of the site can be considered as lost on the average citizen of Marseilles, though not irretrievably so, as evidenced by the periodic 'rediscovery' of the monuments on the blogosphere ${ }^{8}$ - that variant on the conventional 'arenas of articulation' of memory (Ashplant et al. 2000: 17), poised between the public and the private domains - or in the recent efforts of the municipality to draw attention to the site by placing a second, heritage plaque at the corner of the Canebière and the Place $\mathrm{du}$ Général Charles de Gaulle, as a gloss on the original.

In Pierre Nora's definition, a site of memory is one 'where memory is crystallized and finds refuge ... [ranging] from the material and concrete, possibly geographically located, to the most abstract and intellectually constructed' (1984: 1), from the monument in granite or wrought iron, to the archives on paper or online, even to the newsreel. The site's function is 'to stop time, to block the process of forgetting, to ground an event, immortalise death, materialise the immaterial ... and embody a maximum of meaning in a minimum of signs' (38). These three aspects - the material, the functional, and the symbolic - are complementary and co-extensive. Intention is seen as central to the production memory, but what of spontaneous commemorations? As we shall see, the commemoration of the regicide of October 91934 provides one such instance. And if location is optional, as Nora supposes, what should we make of Hawlbachs's emphasis on the necessary spatial dimension: 'place contributes to the stability of the material, it is when fixed in place, enclosed within its limits, and adapted to its conditions, that the collective thought of the group of believers is most likely to stablilize and last' (1967: 165). Place provides the anchorage for and ensures the continuity of memory: its image 'gives us the illusion that nothing has changed over time and that we can uncover the past in the present' (167).

The memorial plaque and the monument to Peace are proximate sites that nonetheless occupy distinctly separate spaces: the former is located in vernacular space (the

\footnotetext{
${ }^{8}$ For instance, see the discussion, under the title 'Assassinat du Roi Alexandre 1er de Yougoslavie et du président Barthou,' of 'a curious monument' near the Préfecture, which was posted to the blog 'Muse s'amuse' on 4 January 2008.
} 
Canebière as a legendary public thoroughfare emblematic of the popular culture of Marseilles), whilst the latter lies within the bounds of civic space (the Préfecture as the House of State). The location of the commemorative sites within the urban geography of Marseilles has polarised remembrance in paradoxical ways: the Canebière's own mythic status in the urban geography of France has partially eclipsed the memorial plaque, while the Pax Monument on the rue de Rome, though the more imposing of the two constructions, has been overshadowed by its proximity to the Préfecture and peripheralised by its distance from the main arteries of the city.

The marginalistion of the Alexander-Barthou memorials raises the issue of geographical scale, of how sites located on the periphery of a polity's territory are assimilated (or not) in the national narrative. In this instance, did the strained core-periphery relations between central and local government conspire to consign the regicide of 9 October 1934 to the footnotes of history? The geography of the Marseilles site is doubly peripheral with a prominent extraterritorial dimension: it commemorates an alliance with a foreign power (Yugoslavia) and the death of a foreign prince (Alexander I), albeit leavened by the loss of a native son (Barthou), in the most Mediterranean and cosmopolitan of France's major cities. The geography also provides a sliding scale of mnemonic perspective, so that French and Yugoslavian perceptions of the importance of the assassination differ markedly, as do points of view within France: remembrance at the centre (Paris) and on the periphery (Marseilles) diverge significantly in the importance accorded to the event.

A related issue is that of the preservation of negative or traumatic episodes in collective memory. In particular, what we might term 'adverse memory,' a sub-category of 'traumatic memory' which includes assassination and political violence, natural catastrophes and accidents inducing collective trauma, such as the fire in the Nouvelles Galeries on the Canebière in 1938 that claimed the lives of 73 people. Blamed on the incompetence of the municipal fire service, it moved central government to suspend the Mayor and municipal council and place Marseilles under the tutelage of a special administrator (Nora 1984: 196). Political violence tends to generate a marginality of its own: in this instance, the assassination is seen to have reinforced 'la mauvaise réputation' of Marseilles as the French Chicago of the 1930s (Joutard 1998: 196). Adverse memories are arguably easier to assimilate when they are battles lost in wars 
won - the 'Dunkirk spirit' would be the clearest example. Antoine Prost makes the point in his contribution to Nora's Lieux de Mémoire on the 'Monuments to the Fallen' in the Prussian and Great Wars: 'Is there less reason to remember 1871 than the victory of 1918 ? [Are these] monuments to the dead, or monuments to victory?' (1984: 196). ${ }^{9}$ While the case of Marseilles is one of civic rather than war memory, and amounts to a diplomatic battle lost well before the outbreak of hostilities, the Second World War is omnipresent in its recollection, although not as a victory: the Defeat of France and the Vichy regime cast a long retrospective shadow over the events of October 1934 in Marseilles.

\section{The struggle over memory}

The public records reveal that the memorialisation of the double assassination was fraught with political controversy and rivalry, between central and local government as well as between the municipality and other memorial agencies in Marseilles (notably the regional press) against a background of local and national party tensions. The commemoration is essentially a tale of two cities - Marseilles and Paris - and of two monuments (aside from the commemorative plaque on the Canebière in Marseilles): the Peace or Pax Monument at the Préfecture and the Monument to Peter I of Serbia, and to his son, Alexander I of Yugoslavia, at the Place de la Muette in Paris. Significantly, it was the Parisian monument, the farthest removed geographically from the scene of events - which was the first of the two to be inaugurated, on 9th October 1936, the second anniversary of the assassination of Alexander I and of Louis Barthou, at a ceremony led by the President of the Republic Albert Lebrun, who delivered the eulogy ('L'amitié franco-yougoslav' 1936: 1) 'exalting the friendship between the two nations, sealed by the blood of their heroes and their martyrs' ('L'hommage de la France' 1936: 1). That the Parisian memorial should have taken precedence over the provincial project is an indication of how swift the capital was to assert its ascendancy in the political tussle over the rights to remembrance. In this, Paris held a material advantage over Marseilles: sculptor Maxime Réal del Sarte's model for a monument to Peter I, King of Serbia, which Alexander was to have viewed in Paris in the course of his ill-fated state visit, was opportunistically extended to include statues of both the fallen king and his

\footnotetext{
${ }^{9}$ 'La défaite de 1871 se serait moins prêtée à commémoration que la victoire de $1918 ?$... Monuments aux morts, ou monuments de la victoire?' (Nora 1984: 196). However, in France's First World War experience, Prost found monuments that were built before the outcome of the war was known or even knowable (196).
} 
former companion-at-arms Marshal Franchet d'Esperey, in a triptych symbolising Franco-Yugoslavian friendship (Degastines 2003).

The timeline of the official response to the double assassination of 9th October 1934 reveals a race to memorialise its victims, which was to bring the principal memorial agencies in Paris and Marseilles into open conflict and expose their opposing interests. Initially, the municipality appeared to have seized the initiative when on Saturday 13 October 1934, the day of Louis Barthou's state funeral, the Mayor of Marseilles Georges Ribot called an extraordinary meeting of the municipal council ('Le Conseil Municipal de Marseille' 1934: 1). The council unanimously adopted four commemorative resolutions put forward by the mayor to honour the victims of 9 October: to name the square opposite the Bourse after Alexander I and one of the streets in the new development behind the Bourse after Louis Barthou; to build a memorial jetty on the Quai des Belges, composed of two columns bearing the effigies of Alexander and Barthou, where Alexander I landed in Marseilles; to place a commemorative plaque on the corner of the Place de la Bourse and the Canebière where the drama unfolded; and finally, to delegate the Mayor to attend Alexander's state funeral in Belgrade ('Le Conseil Municipal a rendu' 1934: 1). Of the monuments and memorials proposed, only the plaque survives today. The square Alexander I opposite the Bourse was rebaptised square Charles de Gaulle in 1970 (Bles 2001: 208-9), ${ }^{10}$ the rue Louis Barthou never materialised and plans for the memorial jetty, which was to have been the centrepiece of the municipality's commemorative project, were shelved. ${ }^{11}$

The tensions which were to frustrate the resolution of the municipal council are already apparent in two communiqués which the Mayor published in quick succession in the wake of the extraordinary council meeting: the first rejects accusations of negligence levelled against the city authorities by unnamed sources in the national press; the second excoriates the authors of an electoral poster exploiting the death of Louis Barthou for electoral purposes ('Le Conseil Municipal de Marseille' 1934: 1). Dr Ribot protested that the municipality had been kept in the dark about the security arrangements made for

\footnotetext{
${ }^{10}$ Confusingly, the historic index of the streets of Marseilles refers to the Square Alexandre I as the 'garden' of the place Général-de-Gaulle, but it is not named as such either on the ground or in contemporary street-plans of the city (Bles 2001:24).

${ }^{11}$ In a memorial lecture given in Marseilles on 10 November 1934, the editor-in-chief of Bourrageas's Petit Marseillais announced that an 'expiatory' monument would be erected to Alexander I in the square opposite the Bourse. Again, this was never to materialise and appears not to have featured in the municipality's original plans. (Bancal 1935: 31).
} 
the King's visit and could be in no way held responsible for the lapse in security which led to his and Barthou's deaths. The assassination took place between the two rounds of the local elections in Marseilles which were being contested by a new party, the Front Français, a heteroclite anti-Popular Front and anti-Marxist formation founded by Simon Sabiani, Deputy Mayor, Member of Parliament for Marseilles's 3rd district, and the power behind the throne in local politics (Témime 2006: 153). ${ }^{12}$ In the new party's ranks, the Radical mayor Ribot - 'une personnalité radicale de second ordre' (a radical of the second division) according to one historian (Témime 2006: 157)—rubbed shoulders with figures as dissimilar as the ultra-conservative press baron Gustave Bourrageas, former militants of the socialist Section Française de l'Internationale Ouvrière (SFIO, French Section of the Workers International) and prominent figures of the Marseilles bourgeoisie. The conflict between Paris and Marseilles over the memorialisation thus unfolded against a background of local party political rivalry, with

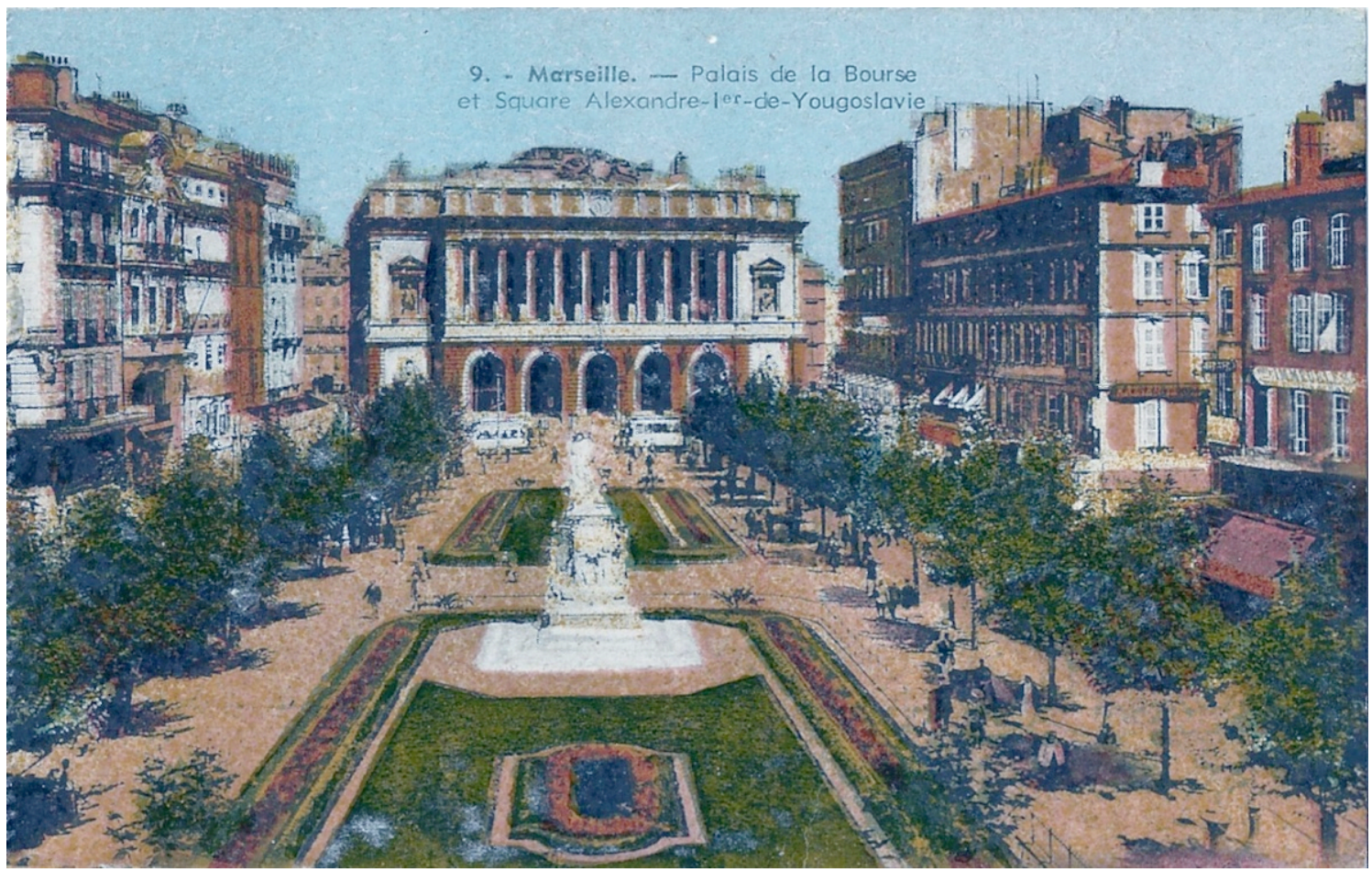

Figure 2: Postcard of Square Alexandre 1er. A. Tardy, photographer, circa 1934. All rights reserved. Alexander I Square was rebaptised Place du Général Charles de Gaulle in 1970.

\footnotetext{
${ }^{12}$ Alèssi Dell'Umbria describes Sabiani, who became Deputy Mayor in 1929 under Ribot's predecessor Siméon Flaissières, as 'a loose cannon' in the political landscape of Marseille, 'an authentic capo of the municipality for four years’ (2006: 477).
} 
ramifications at the national level as well as in the regional broadsheet press: Marseille Matin backed Sabiani and Ribot; the bestselling Petit Marseillais, which supported the conservative shipyard owners in the inter-war years, was owned by Bourrageas. ${ }^{13}$

In his address to the emergency council meeting of 13 October, Mayor Ribot pledged to place the municipality and the people of Marseilles in the vanguard of the public appeal to commemorate the deaths of their distinguished visitors ('Le Conseil Municipal de Marseille' 1934: 1). Unbeknown to him, Paris had already pre-empted that ambition: on 10 October 1934 Marshal Franchet d'Esperey, hero of the Balkan campaign, former comrade-in-arms of Alexander I and Honorary President of the Association of the Friends of Yugoslavia, had formed a special committee 'to build a monument in Marseilles which would perpetuate the memory of our glorious Friend and Ally' (Archives Municipales 1934-36). ${ }^{14}$ The monument was to be located in Marseilles, but built under the direction of his Paris-based veterans' association. Preoccupied with the repatriation of Alexander's mortal remains to Belgrade, the mayor seems to have had no knowledge of the Special Committee's existence, but his sometime ally and political rival Bourrageas evidently did: he cabled Franchet d'Esperey, informing him that his paper the Petit Marseillais had launched its own commemorative appeal 48 hours earlier and suggesting a meeting in Paris 'for mutual assistance [and] amicable conversation' (Archives Municipales 1934-36). ${ }^{15}$ That meeting, chaired by d'Esperey on 13 October at the offices of the Association, brought together the principal memorial agencies with the notable exclusion of the municipality of Marseilles, including representatives of: the Government (in the person of Louis Marin, Minister of Education and Health); Parliament (Edouard Soulier, MP and Vice-Chairman of the Foreign Affairs Committee); the Friends of Yugoslavia Association; the veterans' organisation la Fédération Nationale des Poilus d'Orient; the ex-prisoners of war association la Fédération Nationale des Evadés de Guerre; and the Franco-Yugoslavian Chamber of Commerce. The sole representative from Marseilles in attendance was Gustave Bourrageas, in his capacity as Director of the Petit Marseillais and President of the

\footnotetext{
${ }^{13}$ From the end of the 19th century until 1944, the regional broadsheet press in Provence was dominated by Le Petit Marseillais. Founded and owned by the Bourrageas family, it was a notoriously reactionary paper on the hard right of the political spectrum, and was nicknamed 'le journal des curés' or the 'parish priest's paper' (Journal Officiel de la République Française 1986: 4647). In the inter-war years, Le Petit Marseillais supported the shipping interest in Marseilles.

14 'pour l'érection d'un monument qui perpétuerait à Marseille, la mémoire du glorieux Ami et Allié.'

15 '[pour] concours [et] conversation amicale.'
} 
regional press syndicate. The assembled delegates decided that two monuments would be built: the first in Paris, dedicated to the two kings - Alexander I and Peter I- on the basis of Maxime Real Del Sarte's study, ${ }^{16}$ the second to the victims of the assassination of 9 October in Marseilles. The appeal would be directed by an Honorary Committee in Paris, presided by Franchet d'Esperey, while the building work would be overseen by two executive committees, the first based in Paris, chaired by the MP Edouard Soulier, the second in Marseilles, chaired by Gustave Bourrageas.

The Mayor of Marseilles was not invited to the Paris meeting; nor was he informed of the decisions concerning his city which he seems to have gleaned subsequently from the local press: Marseille Matin commented scathingly on Bourrageas' appointment in its edition of 18 October ('Comité exécutif' 1934: n.p.), to which Bourrageas exercised a curt right of reply on 21 October. The earliest documentary evidence that Ribot knew of the appointment comes from a letter of protest addressed to Franchet d'Esperey on 23 October 1934: 'The city of Marseilles decided to erect a monument to the King immediately following the assassination. Mr Bourageas' nomination can only be provisional, because the chairmanship [of the Marseilles committee] belongs by right to the Mayor of Marseille. Mr Bourrageas only represents a fraction of public opinion' (Archives Municipales 1934-36). ${ }^{17}$ In the archives, Franchet d'Esperey’s reply is dated '13 October, in the evening,' though it was only delivered to the Mairie de Marseille ten days later, on 23 October. Clearly it has been antedated: the recipient (Ribot in person?) has underlined the offending detail twice using the Mayor's trademark blue crayon. Without referring to Ribot's letter (had he received it, or anticipated it?), the author is magnaminous: the committee over which he presides has decided to erect two monuments, one in Paris, the other in Marseilles, which will be 'the work of Marseillais': 'Having accepted the Presidency of the Honorary Committee, in the name of both [executive] committees I would like to invite you, as Mayor, to associate your name and title with the project, by consenting to join our Honorary Committee as Vice-

\footnotetext{
16 'Les Amis de la Yougoslavie' had planned to build a monument to Peter I of Serbia in Orléans, where he had distinguished himself while serving with the French Army in 1870 by escaping across the Loire in spite of his wounds. A rival association, la Fédération des Evadés de Guerre (The Federation of Escaped Prisoners of War), wanted to erect the monument in Paris. The capital was to take precedence.

17 'La ville de Marseille a décidé d'ériger un monument au roi dès l'assassinat. La nomination de M. Bourrageas ne pourrait être que provisoire car la présidence doit revenir au Maire de Marseille. M. Bourrageas ne représente qu'une fraction de l'opinion.'
} 
President' (Archives Municipales 1934-36) ${ }^{18}$ At the same time, the Marshal ostentatiously pulls rank: his organisation is under 'the High Patronage of the President of the Republic'; he has extended the same invitation to the Minister Louis Marin, to Admiral Lacaze (former Minister for the Navy) and to Mr Contenot, Mayor of Paris; he expects 'the moral support and active collaboration of the Marseilles Municipal Council' (Archives Municipales 1934-36). ${ }^{19}$

There follows a long and muddled exchange, complicated by letters overlappingwhere one takes ten days to travel from Paris to Marseilles others take two-and underscored by mutual suspicions of bad faith. After the initial exchange, d'Esperey's letters are written on official, headed note-paper from the General Court Martial. On 25 October, Franchet d'Esperey writes again claiming to have just received Ribot's protest. The tone is more conciliatory: his commemorative committee knew nothing of the Marseilles Municipal Council's deliberations when it met on 13 October, only of the public appeal launched by the regional press; Bourrageas had been invited as the director of Marseilles' leading paper; but the council meeting changes everythingD’Esperey asks Bourrageas to meet with and defer to the Mayor. Ribot accepts his intercession by letter of the same date: 'I am particularly pleased to have received your letter which, I hope, will put an end to this little local misunderstanding which might otherwise have degenerated into a regrettable dispute' (Archives Municipales 193436). ${ }^{20}$ However, the affair was far from over. By October 31 , it is clear from the ensuing correspondence that Bourrageas has refused to stand down as chairman of the Marseilles executive committee, or even to accept the Mayor as co-chairman. Ribot is prepared to cede the chair, but only if Bourrageas withdraws in favour of a 'suitably qualified veteran' of the Great War. The Mayor holds firm on the principle that where any public commemoration in Marseilles is concerned, the local, elected authority must take precedence over other, external or non-elective agencies.

As the period of public mourning began and the municipality erected a temporary Cenotaph to Alexander I and Louis Barthou on the Place de la Bourse, the quarrel

\footnotetext{
18 'Ayant accepté la Présidence du Comité d'Honneur, je viens vous demander, Monsieur le Maire, au nom des deux Comités, de bien vouloir associer votre nom et votre qualité à l'oeuvre entreprise, en acceptant d'entrer dans notre Comité d'Honneur, comme vice-président.'

19 'l'appui moral et la collaboration du Conseil Muncipal de Marseille.'

20 'Je suis particulièrement heureux d'avoir reçu votre lettre qui, je l'espère, mettra fin à quelques petits malentendus locaux susceptibles de dégénérer en regrettables dissentiments.'
} 
rumbled on into November, with Bourrageas obstinately refusing to meet the Mayor. The archival evidence shows that Dr. Ribot had kept his deputy, the MP Sabiani informed of developments and enjoyed his continuing support. We know that moderate politicians of the Left and the Right at the National Assembly regarded Sabiani's demagogy and links to the Marseilles mafia with deep suspicion: on 29 November 1934 Sabiani had organised a public conference at the Salle des Ambassadeurs in Paris to promote his pamphlet about the Marseilles killings that laid the blame on an occult 'Judeo-Masonic' conspiracy with the support of international high finance, revealing nothing of substance beyond the extent of his own swing to the far right, which would culminate in a condemnation to death in absentia for collaboration at the Liberation (Sabiani 1934). ${ }^{21}$ Did concern in Parisian circles about Sabiani's hold on the Marseilles Town Hall fan the flames of discord over the selection and siting of the memorials? Whatever the contributing factors, tensions between the parties still ran high in the summer of $1935 .^{22}$

In the course of the controversy, the Mayor of Marseilles became a symbol of provincial resistance to Jacobin Paris. On 14 December 1934, invited to close the annual congress of the Association of the Mayors of France as keynote speaker, Ribot seized the opportunity to deliver a vibrant requisitory against central government:

The city which I administer has had enough of being treated as a den of vice and a cradle of terrorism. Marseilles has never received enough help from central goverment, in spite of its considerable efforts to expand its economy and overseas trade (...) We wish to remain the true

\footnotetext{
${ }^{21}$ Robert Mencherini reproduces Sabiani's public lecture in an appendix to his study of the crisis years of 1930-40 in Marseilles, Midi rouge, ombres et lumières-1 (2004).

${ }^{22}$ The quarrel came to a head again at the end of the first week in November: on 6 November, Bourrageas called a meeting of the Marseilles Executive Committee for 9 November, to be held at the Préfecture instead of the Mairie. Informed belatedly on 8 November, the Mayor cabled Franchet d'Esperey in Paris: 'Comité Exécutif Marseille devait se rendre à la mairie. J'apprends avec surprise convocation à la Préfecture pour demain. Stop. Dans ces conditions le Maire de Marseille pose sa candidature à la Présidence du Comité de Marseille. Sentiments Respectueux. Dr. Ribot, Maire de Marseille' (Archives Municipales 1934-36) (Marseilles Executive Committee due to meet at Town Hall. To my surprise, learn meeting called for tomorrow at Préfecture. Under such conditions, Mayor of Marseilles candidate for chairmanship of Marseilles Committee. Sincerely yours. Dr. Ribot. Mayor of Marseilles). The threat to oust the Paris appointee was not carried out, but d'Esperey's response was disingenuous: he asked the Prefect to intercede: 'Il nous est impossible de Paris de trancher une question toute locale' (We are in no position to resolve a fundamentally local affair from Paris). An annotation in Ribot's hand suggests the incident is over, but the controversy would carry over into December, when the Mayor's office rejected a request from the Paris executive committee for a financial contribution to the Parisian monument, and would reignite in the spring and summer of 1935, when there was further discord between the town hall and the Marseilles committee over who should organise the national appeal day locally. When Bourrageas called a meeting of the executive committee for the Alexander I-Barthou monument at the Hôtel de Ville for 5 p.m. on July 3, he omitted to inform the Mayor until 4.20 p.m. of the same evening! (Archives Municipales 1934-36).
} 
decision-makers in our cities, living in constant touch with our own citizens (...) The primary and indispensable units of national life, the town halls constitute the backbone of the regime and the buttress of its governance. They want greater freedom. ('Le congrès de l'association' 1934: n.p. $)^{23}$

The polemic between Paris and Marseilles on the one hand, and between the Mairie and the d'Esperey committee's proxy in Marseilles on the other, meant that, more than a year after the assassination, the municipality was still no closer to putting into effect the memorial project voted at the emergency council meeting of the previous October. A memo from the councillor for the Beaux-Arts of 7 December 1935 features only one of the original resolutions - the Alexander I Square opposite the Bourse - in its list of four proposals. Of these, the last, an addition to the site of the Monument des Poilus d'Orient on the Corniche, is crossed out in red. Why? We can only speculate that the conflict with Franchet d'Esperey's veterans' association made it unacceptable to the Town Hall. It still features in fourth position of a list of sites in a subsequent memo of 16 July 1936, from which the Alexander I Square has been deleted. The monumental jetty on the Quai des Belges, once a realistic enough prospect for the municipality to have commissioned a study by the local firm of architects Grebe, had long since been shelved. When President Lebrun inaugurated the Parisian monument in autumn 1936 on the second anniversary of the death of Alexander I, in Marseilles the Pax Monument [see figure 3] had yet to make it onto the drawing board of its designer-to-be, Gaston Castel (Drocourt 1988: 115). Building work on the monument outside the Préfecture would not begin until January 1938 (Noet 2009), the year in which Castel presented the award-winning model of his 'National Monument to King Alexander of Yugoslavia and President Barthou' at the Salon des artistes français ('Monument national' 1938: 1). ${ }^{24}$

By the summer of 1938, plans were being laid for President Albert Lebrun to inaugurate the Marseilles monument, a full two years after its false twin on the Place de la Muette in Paris had been consecrated. By then, Georges Ribot was no longer Mayor of Marseilles, having been been defeated in the municipal elections of 5-12 May 1935 by

\footnotetext{
23 'La ville que j'administre en a assez d'être traitée de sentine du monde et de foyer naturel des attentats. Marseille n'a jamais été aidée suffisamment par le pouvoir central, malgré ses gros efforts personnels d'expansion commerciale et maritime .... Nous désirons rester les véritables chefs de nos cités ; vivant en contact permanent avec nos populations .... Cellules premières et indispensables de la nation, les mairies constituent l'ossature du régime et le soutien des forces nationales, elles demandent plus de liberté.'

${ }^{24}$ The call for tender for the Marseilles monument was eventually made in May 1937. The Castel memorial project, entitled 'Pax et travail' (Peace and work) was shortlisted and subsequently selected on 4 October 1937, but construction work did not begin until January 1938 and took a year to complete.
} 


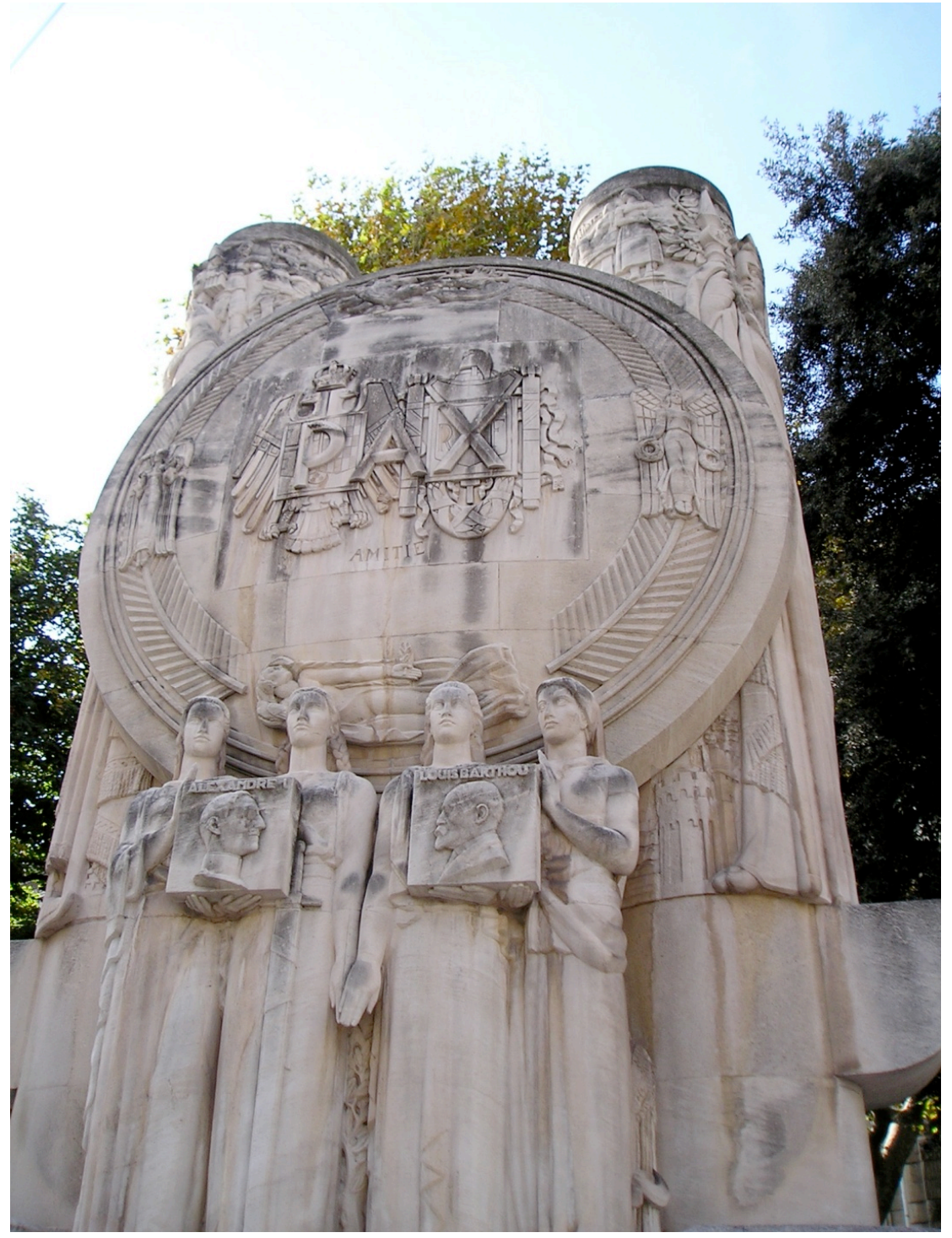

Figure 3: Castel's Pax monument (C) Matthew Graves

Henri Tasso, the leader of the Socialist and Communist alliance, the Common Front (Busquet 1998: 386). The new mayor's deputy wrote on 16 August 1938 to inform him about preparations for the presidential visit 'at the end of the year,' enclosing a detailed program, including an official banquet at the Bourse and a gala evening at the Opera.

However, on the 18 August a handwritten note from the Secretary General of the Mairie to the Director of the Beaux Arts mentions that the presidential visit 'has been postponed by several months' (Archives Municipales 1938). ${ }^{25}$ It was never to materialise. No explanation is given, but we know that the construction of the monument at the Préfecture was not completed until 22 December 1938 (Castel 2009). In the interval, an unrelated incident would consummate the political divorce between

25 'a été reportée de quelques mois.' 
central government and the Marseilles municipality, and make any presidential visit unthinkable.

\section{Counter-memories}

The fire that engulfed the Nouvelles Galeries on the Canebière on 28 October 1938, claiming seventy-three lives, was witnessed by the President of the Council Daladier, the President of the Assembly Herriot, and the Minister of the Interior Sarraut, all of whom were attending the National Congress of the Radical Party nearby. The ensuing controversy over the responsibility of the municipal authorities, compounded by the political and personal antipathy between the Radical Daladier and the Socialist Tasso, led to the decree of 20 March 1939 that deprived Marseilles of its elected Mayor and placed the city under the tutelage of central government in the person of a special administrator appointed directly by the President of the Republic, ${ }^{26}$ 'a colonial governor' in the words of its senior councillor (Baratier 1973: 421). In August 1940, the functions of special administrator and prefect for the department of the Bouches-duRhône would be merged in the person of a single 'Prefect adminstrator-delegate' (Busquet 1998: 387). The final chapter in the long-running feud between the Mairie and central government would thus see the centre of gravity in decision-making shift decisively and durably (the 'régime d'exception' would last until the Liberation in August 1944) from the Town Hall to the Préfecture, just as the national monument to Alexander-Barthou rose from the ground outside it.

Under these conditions, and in the deteriorating national and international political climate, it is hardly suprising that the Pax Monument would never be given a republican inauguration or indeed serve the memorial purpose for which it was originally designed. By the time of its completion, the Popular Front government had lost power and the Pax Gallica for which it stood was increasingly equated with appeasement. The foreign policy pursued by Alexander I's successor, the Prince Regent Paul, had carried Yugoslavia into the diplomatic orbit of the Axis. There is no record of the site being used for public ceremony before the Second World War. However, on 28 March 1941, with Marseilles now under the tutelage of the Vichy government, it became the scene of the first major public protest against the Axis powers in Marseilles. In celebration of the

\footnotetext{
${ }^{26}$ B.M.O. $\mathrm{n}^{\mathrm{o}} 1901 \mathrm{du} 25$ mars 1939. Stripped of his mayoral attributes, Henri Tasso was demoted to the chairmanship of the Municipal Council.
} 
pro-Allied coup d'état which brought Alexander's son, Peter II, to power in Yugoslavia on 27 March 1941, the students' resistance movement in Marseilles organised the flowering of the commemorative plaque opposite the Bourse as well as of the BarthouAlexander monument outside the Préfecture, stuffing their bouquets with anti-German propaganda ('La Manifestation Patriotique' 2005: 16). They were joined by thousands of Marseillais in a popular gesture of defiance which was surprisingly tolerated by the police, who are reported to have removed the bouquets the following day only to deposit them minus the anti-German tracts, at the foot of the Monument aux Mobiles de 1870 commemorating the Franco-Prussian war (16). Bourrageas's paper the pro-Vichy Le Petit Marseillais, pointedly downplayed the incident as the spontaneous outpouring of loyalty by members of the Yugoslavian community of Marseilles ('Des fleurs sur la plaque' 1941: 1), ${ }^{27}$ but the international press saw it as a turning point in the public's perception of the Vichy regime ('Thousands in Marseilles' 1941: 1). ${ }^{28}$

On 20 June 1941, the Pax Monument was finally inaugurated, almost seven years after the event it was designed to commemorate, when the Marseilles executive committee handed over responsibility for the site to the city authorities in a low-key ceremony held in the absence of any senior government official ('La remise à la ville' 1941: 2). Was the ceremony designed as the Vichy administration's response to the public protests of 27 March, in an effort to 'normalise' the monument and restore its official commemorative purpose as a symbol of a pro-Axis Franco-Yugoslavian alliance? If that is the case, it is perhaps no accident that the inauguration should coincide with the flight of Peter II to London at the head of the Yugoslavian government in exile ('Le roi Pierre II' 1941: 3).

\section{Conclusion}

The core-periphery tensions over the memorialisation of 9 October 1934 delayed the building of the Marseilles monument to such an extent that by the time it was unveiled it had lost much of its symbolic significance. Indeed, in the wake of the assassination, Yugoslavia became diplomatically estranged from France, eventually forming the Tripartite Pact with the Axis, and by 1938 the Franco-Yugoslavian special relationship

\footnotetext{
${ }^{27}$ Gustave Bourrageas died in 1940 and was succeeded by first Paul and later Jean Gaillard-Bourrageas. The latter was condemned to death at the Liberation for collaboration.

${ }^{28}$ The same source reports that the statue of King Peter I of Serbia, Alexander's father and Peter II's grandfather, was bombed in Zagreb on 29 March, a case of a memorial becoming the target of symbolic violence.
} 
was null and void. Furthermore, under pressure from d'Esperay's Paris committee, the relocation of the Marseilles monument to official, civic space outside the Préfecture deprived the memorial of its vernacular meaning as the 'people's monument' and thereby of its expiatory function as a conduit for adverse memory. As the controversy over the memorial mounted, opinion in the Marseilles press and other public forums would repeatedly question whether a monument should be built at all —wouldn't it be better to forget what amounted to a stain on the city's reputation? With the demise of the Popular Front and the advent of the Second World War, the very idea of a monument to the Peace must have seemed redundant. Thereafter, the Marseilles monument could only function effectively as a site of counter-memory, briefly becoming the focus for popular resistance to the Vichy regime and to the German occupation of France, in the form of a spontaneous commemoration which was as much about the living (Peter II) and the political present as it was about the dead (Alexander I). Arguably, the failure of the Marseilles monument as a site of memory has been compounded by the relegation of the episode to the footnotes of national history, a process in which the foreign ministeries of Britain and France, in their readiness to forego an international enquiry and 'forget' in the interests of appeasement, initially played no small part (Kovrig 1976). The subsequent course of European history would do the rest: after 1945, the Cold War, the exile of the Yugoslavian monarchy, the advent of Tito's communist regime, and the demise of the Franco-Yugoslavian alliance, would deprive Marseilles and France of reasons to remember the events of 9 October 1934.

\section{Acknowledgments}

I would like to thank the staff of the Archives Municipales of Marseilles for their support and assistance in tracing the sources for this paper, and in particular the curator Marie-Noëlle Perrin. I am grateful to Emmanuelle Reimbold for sharing her expert knowledge of the life and work of Gaston Castel as she was preparing the exhibition 'Gaston Castel. Les Territoires de l'Architecte,' at the Archives départementales des Bouches-du-Rhône, Marseilles (13), 18 September-19 December 2009. As this paper went to press a related exhibition was underway in Marseilles: 'Architecture et Décor à Marseille, 1919-1965: Gaston Castel et les Artistes,' and I would like to thank the Musée de l'Histoire de Marseille for the opportunity to view the sketches, plans and models of Castel's memorial project. I am indebted to the art historian Laurent Noet for his detailed account of the Castel monument and to both Laurent and Emmanuel Laugier at the Atelier du Patrimoine de la Ville de Marseille for throwing light on the date and circumstances of the inauguration of the Pax Monument. Finally, I owe a debt of gratitude to my colleagues, the political historians Laurence Americi and Robert Mencherini for their patient and expert guidance through the maze of Marseilles politics in the 1930s. 


\section{Reference List}

'L'amitié franco-yougoslav s'est affirmée devant le monument des rois Pierre et Alexandre', 10 oct. 1936, Le Figaro, 1.

Archives Municipales de Marseille, 1938, 614W, Article 144.

Archives Municipales de Marseille, 1934-36, Série M Sous-Série 32 M, Article 29.

Ashplant, T. G., et al. 2000, The Politics of War Memory and Commemoration. Routledge, London.

'Assassinat du Roi Alexandre 1er de Yougoslavie et du président Barthou.' 2008, Blog Muse s'amuse, 4 jan. Online, available: http://amuse1.blogspot.com/2008/01/assassinat-du-roi-alexandre-1erde.html [Accessed 20 March 2010].

Bancal, L. 1935, Alexandre $1^{\text {er }}$ l'Unificateur et la Yougoslavie. Imprimerie de la Société du Petit Marseillais, Marseille.

Baratier, E. (ed.) 1973, Histoire de Marseille. Privat Editeur, Toulouse.

Bles, A. 2001, Dictionnaire historique des rues de Marseille: Mémoire de Marseille. Editions Jeanne Laffitte, Marseille.

Borne, D. \& Dubief, H. 1989, La crise des années 30, 1929-38. Editions du Seuil, Paris.

Bouillon, J., Sorlin, P. \& Rudel, J. 1968, Le monde contemporain. Bordas, Paris.

Bouillon, J., Sohn, A. \& Brunel, F. 1980, Le monde contemporain, 1914-45. Bordas, Paris.

Boura, O. 2001, Marseille ou la mauvaise réputation. Arléa, Paris.

Bousquet, R. \& Vautravers, C. 1998, Histoire de Marseille. 2nd ed., Editions Robert Laffont \& Editions Jeanne Laffitte, Marseille.

Cabinet 34, The National Archives, ref. CAB/23/80, 10 oct. 1934, 28.

Castel, G. 2009, Architecture et décor à Marseille, 1919-1965: Gaston Castel et les artistes. Musée d'Histoire de Marseille/Images en Manoeuvres Editions, Marseille.

'Comité exécutif pour l'érection à Marseille d'un monument à la mémoire d'Alexandre de Yougoslavie,' 18 oct. 1934, Marseille Matin, n.p.

'Le Conseil Municipal a rendu un solennel hommage aux illustres victimes de l'attentat du 9 octobre,' 15 oct. 1934, Le Petit Marseillais, n.p.

'Le Conseil Municipal de Marseille réuni en séance extraordinaire rend un solennel hommage au Roi Alexandre, à M. Louis Barthou et aux autres victimes de l'attentat,' 15 oct. 1934, Marseille Matin, n.p.

Crane, S. 2004, 'Digging up the Present in Marseilles' Old Port: Toward an Archaeology of Reconstruction,' The Journal of the Society of Architectural Historians, vol. 63, no. 3 (Sep.), 296319.

Cresswell, T. 2004, Place: A Short Introduction. Blackwell, Oxford.

Deac, W. 1998, 'The Assassinations of the French Foreign Minister and the President of Yugoslavia Signaled the Approach of WWII,' World War II, vol. 13, no. 3 (Sep. 18). Online, available: http://web.ebscohost.com.rproxy.univ-provence.fr:2048/ehost [Accessed 23 Oct. 2008].

Degastines, C. 2003, 'Le monument de la Place de la Muette à Paris.' 15 juin. Online, available: http://pagesperso-orange.fr/cdg\%20/CDG15_06_2003.html [Accessed 23 Oct. 2008].

Dell'Umbria, A. 2006, Histoire universelle de Marseille de l'an mil à l'an deux mille. Agone, Marseille.

'Des fleurs sur la plaque commémorative de la Bourse et devant le monument du roi Alexandre de Yougoslavie,' 29 mars 1941, Le Petit Marseillais, 1.

Drocourt, D. (ed.) 1988, Gaston Castel: Architecte marseillais. Edisud/Musée de Marseille, Aix-enProvence.

Dutour, J. 2006, 'Les plaques commémoratives: Entre appropriation de l'espace et histoire publique de la ville,' Les Mondes du Patrimoine, Socio-Anthropologie, no.19. Online, available: http://socioanthropologie.revues.org/document603.html [Accessed 19 Oct. 2008].

Eden, A. 1962, Facing the Dictators. Cassell, London.

Gildea, R. 1994, The Past in French History. Yale University Press, New Haven \& London.

Guiral, P. \& Amargier, P. 1983, Histoire de Marseille. Mazarine, Paris.

Halbwachs, M. 1967, La mémoire collective. 2nd ed., Les Presses universitaires de France, Paris.

'L'hommage de la France à deux grands rois,' 10 oct. 1936, Le Petit Parisien, 1.

Journal Officiel de la République Française, Débats Parlementaires, Assemblée nationale, 11 Oct. 1986, 4647.

Joutard, P. 1998, L'Histoire de Marseille en treize evénements. Editions Jeanne Laffitte, Marseille.

'King's Statue Bombed,' 29 March 1941, Pittsburgh Post-Gazette, 2.

Kovrig, B. Mar. 1976, 'Mediation by Obfuscation: The Resolution of the Marseilles Crisis, October 1934 to May 1935,' The Historical Journal, vol. 19, no. 1, 191-221.

Macmillan, H. 1966, Winds of Change, 1914-39. Macmillan, London. 
McNamee, G. 1934, 'Alexander Murdered.' Universal Newsreel, Oct.

'La Manifestation Patriotique du 28 mars 1941 à Marseille,' Septembre 2005, La Lettre de la Fondation de la Résistance, no. 42, 16.

'La remise à la ville du monument du roi Alexandre et du président Barthou,' 21 juin 1940, Le Petit Provençal, 2.

'Le congrès de l'association des maires de France,' 15 dec. 1934, Le Matin, n.p.

'Le roi Pierre II de Yougoslavie est arrivé à Londres,' 22 juin 1941, Le Petit Provençal, 3.

Mencherini, R. 2004, Midi rouge, ombres et lumières-1. Une histoire politique et sociale de Marseille et des Bouches-du-Rhône de 1930 à 1950. Les années de crise 1930-40. Syllepse, Paris. 2009, Vichy en Provence: Midi rouge, ombres et lumières-2. Syllepse, Paris.

'Monument national du roi Alexandre de Yougoslavie et du président Barthou,' 3 juillet 1938, $\mathrm{La}$ Construction Moderne, 1.

Noet, L. 2009, Le monument à la Paix (Antoine Sartorio, Louis Botinelly, Elie-Jean Vézin sculpteurs). 12 mars. Online, available: http://marseillesculptee.blogspot.com/search/label/Castel\%20Gaston\% 20\%28A\%29 [Accessed 20 March 2009].

Nora, P., et al. 1984, Les lieux de mémoire, t. 1 La République (1 vol.). Gallimard, Paris.

Rousso, H. 1991, The Vichy Syndrome: History and Memory in France since 1944. Harvard University Press, Cambridge.

Sabiani, S. 1934, La vérité sur l'attentat à Marseille. Editions des Ambassadeurs, Paris.

Seton-Watson, R. W. 1932, 'The Yugoslav Dictatorship,' International Affairs (Royal Institute of International Affairs 1931-1939), vol. 11, no. 1 (Jan.), 22-39. 1935, 'King Alexander's Assassination: Its Background and Effects,' International Affairs (Royal Institute of International Affairs 1931-39), vol. 14, no. 1 (Jan.-Feb.), $20-47$. 1929, 'Jugoslavia and Croatia,' Journal of the Royal Institute of International Affairs, vol. 8, no. 2 (March), 117-33.

Témime, E. 2006, Histoire de Marseille. Jeanne Lafitte, Marseille.

'Thousands in Marseilles Cheer Yugoslavia Stand,' 29 March 1941, Pittsburgh Post-Gazette, 1.

Warner, G. 1968, Pierre Laval and the Eclipse of France. Eyre \& Spottiswoode, London. 